\title{
Energy analysis of broiler chicken production system with darkhouse installation
}

\author{
Matheus C. Mattioli ${ }^{1}$, Alessandro T. Campos ${ }^{2}$, Tadayuki Yanagi Junior², \\ Diego B. Marin ${ }^{1}$, Tony M. C. Eugênio ${ }^{3}$ \& José E. V. Costa Junior ${ }^{4}$
}

${ }^{1}$ Universidade Federal de Lavras/Programa de Pós-Graduação em Engenharia Agrícola. Lavras, MG. E-mail: matheus_mattioli@yahoo.com.br (Corresponding
author) - ORCID: 0000-0001-7769-3392; db.marin@hotmail.com - ORCID: 0000-0001-7526-0825
${ }^{2}$ Universidade Federal de Lavras/Departamento de Engenharia. Lavras, MG. E-mail: campos@deg.ufla.br - ORCID: 0000-0002-4653-9453; yanagi@deg.ufla.br -
ORCID: 0000-0001-9653-205X
${ }^{3}$ Universidade Federal de Lavras/Programa de Pós-Graduação em Engenharia de Biomateriais. Lavras, MG. E-mail: tony.matheus@hotmail.com - ORCID: 0000-
0001-7049-2862

${ }^{4}$ Universidade Federal de Lavras/Programa de Pós-Graduação em Engenharia Florestal. Lavras, MG. E-mail: jevcjunior@gmail.com - ORCID: 0000-0002-5049-2029

\section{Key words:}

sustainability

input-output analysis

livestock buildings and environment

aviculture

broiler chicken facilities

\begin{abstract}
A B S T R A C T
The objective of this study was to evaluate the sustainability of a broiler chicken production system, with confinement in Darkhouse sheds, by energetic analysis. Energy flows of a complete production cycle, 56 days, were considered, of which the energy inputs and outputs were computed in direct and indirect forms, by estimating the energy coming from the quantity of feed, water, machinery and equipment, human labor, sheds, silos, among other components of the productive system, multiplied by their respective energetic coefficients. The total energy demand of a system in a production cycle for the production of $1 \mathrm{~kg}$ of live chicken and its energy efficiency coefficient were determined. The studied system had energy conversion coefficient of $95 \%$, demonstrating that the production model has high energy conversion efficiency and fits a sustainable model. On average, $37.55 \mathrm{MJ} \mathrm{kg}^{-1}$ of live chicken were necessary. The main limiting point of the system corresponded to the energy consumed in the form of feed, with $75 \%$ of the total direct energy.
\end{abstract}

Palavras-chave: sustentabilidade balanço de energia construções rurais avicultura instalações para aves de corte

\section{Análise energética de sistema de produção de frangos de corte em instalação do tipo Darkhouse}

\begin{abstract}
R E S U M O
Uma interessante maneira de se mensurar a eficiência de sistemas produtivos é por meio da análise energética, identificando quais insumos ou operações demandam mais energia. Portanto, objetivou-se no presente trabalho avaliar a eficiência energética de um sistema de criação de frangos de corte, confinados em galpões com tipologia Darkhouse. Foram considerados os fluxos de energia referentes a um ciclo completo de produção, 56 dias, onde foram computadas as entradas e saídas de energia, na forma direta e indireta, por meio da estimação da energia presente na ração, água, máquinas e equipamentos, trabalho humano, galpões, silos, dentre outros que compõem o sistema produtivo, multiplicando-se pelos seus respectivos coeficientes energéticos. Foram encontradas a demanda total de energia pelo sistema em um ciclo de produção, a energia necessária para produção de $1 \mathrm{~kg}$ de frango vivo e o coeficiente de eficiência energética do mesmo. O sistema estudado apresentou um coeficiente de conversão da energia de $46 \%$, valor próximo ao encontrado para sistemas de produção animal. Foram necessários, em média, $37,55 \mathrm{MJ} \mathrm{kg}^{-1}$ de frango vivo. O principal ponto estrangulador do sistema correspondeu à energia consumida na forma de ração, com $75 \%$ do total da energia direta.
\end{abstract}




\section{INTRODUCTION}

Broiler chicken production systems have become increasingly more technological, importing modern and automation-based scientific practices to obtain higher energetic efficiency and maximum economic benefit (Heidari et al., 2011), as in the case of the Darkhouse broiler chicken production system, which are highly efficient in food conversion compared with the conventional production system, obtaining significantly higher production (Carvalho et al., 2015).

A mechanism used to evaluate the efficiency of production systems is the energy balance, which establishes the energy flows inherent to the production, identifying its efficiency in energy conversion through the energy converted/energy consumed ratio and also the energy needed to produce $1 \mathrm{~kg}$ of product (Veloso et al., 2012). According to Ebrahimi et al. (2016), if inefficient producers were aware of the most energyconsuming inputs within their processes, they would be able to considerably improve economic and energetic aspects.

In this context, there is a scarcity of analyses and specific energy coefficients for certain studied components, which include the fossil energy consumed during the extraction, manufacture and transport of the raw materials and other products, adapted to the current and local conditions of the studied area (Vigne et al., 2012).

Thus, this study aimed to conduct an energy analysis of a broiler chicken production system, in Darkhouse-type system, determining its energetic efficiency and total energy demand and measuring the conditions relative to energy sustainability of the biosystem studied.

\section{Material ANd Methods}

The study was carried out in a commercial chicken farm, belonging to the group Frangos Atalaia, located in the municipality of Coronel Xavier Chaves, Minas Gerais state, Brazil. The region has an average altitude of $970 \mathrm{~m}$, latitude $21^{\circ}$ $02^{\prime} 42^{\prime \prime}$ South and longitude $44^{\circ} 10^{\prime} 10^{\prime \prime}$ West, with subtropical humid climate (Cwa), according to the Köppen-Geiger climate classification.

The study period comprised a complete cycle of chicken production, i.e., 56 days. This period included 11 days of downtime, which involved operations to remove the chicken bedding from the previous cycle, sanitation of the shed, rest and distribution of new bedding material destined to the new lot, and approximately 45 days for the arrival of 1-day-old chicks, growth, fattening and exit of the animals for slaughter.

The boundary of the system was delimited to coincide with the total area relative to the production activities, with approximately $40,000 \mathrm{~m}^{2}$, having two Darkhouse-type sheds, caretaker's house, composters to dispose dead animals, generator shelter, two conical bottom silos for feed storage and a set of water tanks.

In the energy balance methodology, it is necessary to take into account all energy inputs and outputs in the system's boundaries, where the inputs are classified as direct and indirect (Angonese et al., 2006; Souza et al., 2009; Jasper et al., 2010; Veloso et al., 2012, 2014). Direct energies are those consumed or fully incorporated in the studied period, while indirect energy contributes in more than one productive cycle, and its energy cost is diluted throughout the component's lifetime.

According to historical information of the company, the daily feed consumption is $7,100 \mathrm{~kg}$ and the average water requirement is $16,000 \mathrm{~L}$, for the two aviaries. The tractors used for transport, deposition and turning of the bedding consumed a total of $320 \mathrm{~L}$ of fuel. 30 tons of sawdust were deposited in each aviary as bedding material.

The energy quantification of facilities, machinery and equipment was based on the energy depreciation during their lifetime. In this case, we considered 56 days of use of the entire infrastructure of the property, energetically depreciated according to the lifetime inherent to each component and with the aid of their respective manuals, as performed by Pimentel (1980), Campos et al. (2003), Santos \& Lucas Júnior (2004), Heidari et al. (2011) and Veloso et al. (2012, 2014).

After the downtime, the sheds received 78,000 birds in $4,959 \mathrm{~m}^{2}$, each bird with approximately $46.5 \mathrm{~g}$. At the end of the cycle, the animals had an average weight of $2.6 \mathrm{~kg}$, totaling $197,600 \mathrm{~kg}$ of live weight and with an average deposition of 220 tons of waste on the bed, which was sold to vegetable producers in the region.

Energy balance was calculated considering all energy inputs in the system, divided into direct energy - DE (Table 1) and indirect energy - IE (Table 2). Then, the quantities were converted into energy units, obtaining the total amount of energy exiting in the system, thus ending the energy balance.

The energetic efficiency of the system ( $\eta$ ) was calculated using the following equation:

$$
\eta=\frac{\sum \mathrm{E} \text { Converted }}{\sum \mathrm{E} \text { Consumed }}
$$

Table 1. Inputs of direct energy (DE) and their respective energetic coefficients

\begin{tabular}{lccl}
\hline \multicolumn{1}{c}{ Direct inputs } & Quantity & Energetic coefficient & \multicolumn{1}{c}{ Reference } \\
1-day-old chicks & $905.7 \mathrm{~kg}^{*} \mathrm{DM}$ & $21.94 \mathrm{MJ} \mathrm{kg}^{-1} \mathrm{DM}^{-1}$ & Santos \& Lucas Júnior (2004) \\
Feed & $320,000.0 \mathrm{~kg}$ & $17.46 \mathrm{MJ} \mathrm{kg}^{-1}$ & Angonese et al. (2006) \\
Water & $720,000.0 \mathrm{~L}$ & $0.63 \mathrm{MJ} \mathrm{m}^{-3}$ & Yilmaz et al. (2005) \\
Electricity & $8,971.4 \mathrm{kWh}$ & $5.65 \mathrm{MJ} \mathrm{kWh}^{-1}$ & Meul et al. (2007) \\
Diesel & $320.0 \mathrm{~L}$ & $47.48 \mathrm{MJ} \mathrm{L}^{-1}$ & Pimentel (1980) \\
Lubricants & $20.0 \mathrm{~kg}$ & $43.38 \mathrm{MJ} \mathrm{kg}^{-1}$ & Jasper et al. (2010) \\
Sawdust for poultry bed & $60,000.0 \mathrm{~kg}$ & $19.20 \mathrm{MJ} \mathrm{kg}^{-1}$ & Funck \& Fonseca (2008) \\
Firewood for furnace & $28,800.0 \mathrm{~kg}$ & $19.20 \mathrm{MJ} \mathrm{kg}^{-1}$ & Funck \& Fonseca (2008) \\
Human labor & $1,888.0 \mathrm{~h}$ & $0.39 \mathrm{MJ} \mathrm{h}^{-1}$ & Fernandes \& Souza (1982) \\
Veterinary inputs & $160.0 \mathrm{~kg}$ & $99.00 \mathrm{MJ} \mathrm{kg}^{-1}$ & Mudahar \& Hignett (1987) \\
\hline
\end{tabular}

* Dry matter 
Table 2. Inputs of indirect energy (IE) relative to facilities, machinery and equipment, and their respective coefficients

\begin{tabular}{lclll}
\hline \multicolumn{1}{c}{ Indirect inputs } & Quantity & Lifetime & Energetic coefficient & Reference \\
Darkhouse sheds & $1,558.8 \mathrm{~m}^{2}$ & 40 years & $1,208.17 \mathrm{MJ} \mathrm{m}^{-2}$ & Campos et al. (2003) \\
Composter & $59.0 \mathrm{~m}^{2}$ & 40 years & $1,208.17 \mathrm{MJ} \mathrm{m}^{-2}$ & Campos et al. (2003) \\
Electric generator shelter & $50.4 \mathrm{~m}^{2}$ & 40 years & $1,208.17 \mathrm{MJ} \mathrm{m}^{-2}$ & Campos et al. (2003) \\
Fiberglass water tank & $67,000.0 \mathrm{~L}$ & 40 years & $46.30 \mathrm{MJ} \mathrm{kg}^{-1}$ & Heidari et al. (2011) \\
Steel silos for feed & $29,900.0 \mathrm{~kg}$ & 25 years & $62.78 \mathrm{MJ} \mathrm{kg}^{-1}$ & Pimentel (1980) \\
Automated systems & $3,450.9 \mathrm{~kg}$ & 10 years & $83.68 \mathrm{MJ} \mathrm{kg}^{-1}$ & Santos \& Lucas Júnior (2004) \\
Bobcat Tractor & $2,465.0 \mathrm{~kg}$ & $10,000 \mathrm{~h}$ & $57.20 \mathrm{MJ} \mathrm{kg}^{-1}$ & Pimentel (1980) \\
Husqvarna TR 430 Tractor & $92.0 \mathrm{~kg}$ & $10,000 \mathrm{~h}$ & $57.20 \mathrm{MJ} \mathrm{kg}^{-1}$ & Pimentel (1980) \\
Generator & $2,747.0 \mathrm{~kg}$ & $10,000 \mathrm{~h}$ & $57.20 \mathrm{MJ} \mathrm{kg}^{-1}$ & Pimentel (1980) \\
Furnaces & $1,080.0 \mathrm{~kg}$ & 15 years & $62.78 \mathrm{MJ} \mathrm{kg}^{-1}$ & Pimentel (1980) \\
Dump truck & $23,000.0 \mathrm{~kg}$ & $10,000 \mathrm{~h}$ & $57.20 \mathrm{MJ} \mathrm{kg}^{-1}$ & Pimentel (1980) \\
\hline
\end{tabular}

where:

$\sum$ Energy Consumed $=\Sigma($ ED consumed + IE consumed $)$

Energy Converted - estimate of energy existing in the production process;

Energy Consumed - estimate of input energy involved in the production process;

ED - estimate of direct energy; and,

IE - estimate of indirect energy.

\section{Results AND Discussion}

To obtain the total energy involved in the process, we calculated the conversion of the quantities of inputs used in one production cycle, represented by the direct energy inputs and also the costs inherent to the energy-based depreciation, indirect energy, relative to 56 days of utilization of the components which contributed in more than one production cycle.

Table 3 presents the main components used in the system and their respective energetic contributions, representing the direct and indirect energy inputs of this energy balance study.

Table 3. Direct (DE) and indirect energy (IE) inputs in the broiler chicken production system expressed in MJ

\begin{tabular}{|lr}
\hline \multicolumn{1}{|c}{ Inputs } & Input energy (MJ) \\
\hline Direct energy & \\
\hline 1-day-old chicks & $19,870.22$ \\
\hline Feed & $5,587,200.00$ \\
\hline Water & 453.60 \\
\hline Electricity & $50,688.41$ \\
\hline Diesel & $15,193.60$ \\
\hline Lubricants & 867.60 \\
\hline Sawdust for poultry bed & $1,152,000.00$ \\
\hline Firewood for furnace & $552,960.00$ \\
\hline Human labor & 729.52 \\
\hline Veterinary inputs & $15,540.00$ \\
\hline & $7,395,502.95$ \\
\hline Indirect energy & \\
\hline Darkhouse sheds & $7,222.44$ \\
\hline Composter & 273.37 \\
\hline Electric generator shelter & 233.52 \\
\hline Fiberglass water tanks & 92.04 \\
\hline Steel silos for feed & 231.17 \\
\hline Automated systems & 442.98 \\
\hline Bobcat Tractor & $4,229.94$ \\
\hline Husqvarna TR430 Tractor & 151.56 \\
\hline Electric generator & 754.22 \\
\hline Furnaces & 692.94 \\
\hline Dump truck & $10,524.80$ \\
\hline & $24,848.97$ \\
\hline & $7,420,351.92$ \\
\hline
\end{tabular}

The largest amount of direct energy entering the system came from the feed, $75 \%$, a fact also observed by several authors such as Santos \& Lucas Júnior (2004), who carried out the energy balance of a conventional broiler chicken production system in which the item feed was the most energy-demanding input, representing $86.50 \%$ of the total direct energy. This input, as verified in the literature, represents the main choke point of modern agricultural production systems.

Working with energy analysis of a deep bed swine production system, Veloso et al. (2012) also identified the feed as the item that most required energy in direct form, $80.57 \%$, which is close to that observed by Souza et al. (2009), 80.26\%, and Lammers et al. (2012), with $81.02 \%$ of the direct energy inputs coming from the feed. However, the value found by Veloso (2014) represents almost all the energy spent directly, contributing with $98.18 \%$ of the total direct input in a fullcycle swine production system with conventional facilities.

In this context, in a similar study, Angonese et al. (2006) pointed the expenditure of $95.28 \%$ of direct energy with feed, demonstrating that as in the present study the feed is the input with highest energy demand in meat production systems, thus characterizing the main limiting point with respect to energy in the studied systems. It is necessary to develop diets or technologies for higher food conversion or lower expenditures with feed, ensuring higher increments in production.

The second largest energy consumer was wood, used as both bedding material for chickens and energy source to heat young animals, contributing with $23.05 \%$ of the total direct energy entering the system. According to Funck \& Fonseca (2008), the energy spent to heat chickens using firewood was 173.21 GJ lot $^{-1}$, while the one found in this study was from $276.48 \mathrm{GJ}$ lot $^{-1}$, possibly due to the larger size of the area that was heated in the studied sheds, approximately $4,950 \mathrm{~m}^{2}$ for both sheds, against $1,200 \mathrm{~m}^{2}$ of internal area in the study of the previously mentioned authors.

Also regarding the energy expenditure with wood, more specifically with chicken bedding material, there was expenditure of $15.52 \%$ of the total direct inputs. Likewise, Santos \& Lucas Júnior (2004) computed a total expenditure of $121.77 \mathrm{MJ}$ or $4.96 \%$ of the total energy entering the system coming from the wood shavings used as chicken bedding material. In the energy balance performed by Veloso et al. (2012), the expenditure with the deep bed made of sawdust, same material used in the system under study, was of the order of $11.90 \%$ of the energy inputs. 
Table 4. Energy outputs of the broiler chicken production system expressed in MJ

\begin{tabular}{lccccc}
\hline \multicolumn{1}{c}{ Energy outputs } & Quantity & Energetic coefficient & Reference & Output energy (MJ) \\
\hline Poultry litter and composting of animals & $98,956 \mathrm{~kg} \mathrm{DM}$ & $15.23 \mathrm{MJ} \mathrm{kg}^{-1} \mathrm{DM}^{-1}$ & Santos \& Lucas Júnior & $1,507,099.88$ \\
Live chicken for slaughter & $73,784 \mathrm{~kg} \mathrm{DM}^{-1}$ & $25.81 \mathrm{MJ} \mathrm{kg}^{-1} \mathrm{DM}^{-1}$ & $(2004)$ & $1,904,365.04$ \\
\hline
\end{tabular}

As for the use of electricity, the expenditure per production cycle was equal to $50,688.41 \mathrm{MJ}$, or $0.7 \%$ of the total employed in the system, higher than the value found by Santos \& Lucas Júnior (2004), 0.4\%, which can be explained by the high requirement in electricity of the automated production systems, particularly the Darkhouse-type systems, which are extremely energy-dependent for the operation of equipment and controllers.

Values of indirect energy inputs were obtained by calculating the energetic depreciation, i.e., depreciation in energetic terms of the components involved in one production cycle, based on the number of hours of operation relative to their lifetime and weight. The highest contribution of energy comes from the machines, which are used for transport and management of poultry litter, 42.35 and $17.63 \%$ corresponding to the truck and tractors, respectively.

The second component with greatest contribution was the facilities, $29.06 \%$ of the total of indirect energy inputs. The total percentage of energy used in direct form was $0.33 \%$, whereas the remaining $99.67 \%$ corresponded to direct energy. Similar proportions were not found in studies on energy balance in broiler chicken production system, but Souza et al. (2009) found the proportion of 98.25 to $1.75 \%$ in the consumption of indirect and direct energy, respectively. An even closer value to that obtained in the present study refers to the swine production system, in which $99.70 \%$ of the energy used was in direct form (Veloso et al., 2012). In study on broiler production for slaughter, Santos \& Lucas Júnior (2004) found that $51.2 \%$ of the energy entering the system come from the energy of machinery and equipment, whereas $48.8 \%$ correspond to direct energy.

According to Table 4, the main energy outputs of the system corresponded to broiler chickens (meat) and composting material (organic manure), disregarding the losses represented by water vapor and gases (carbon dioxide, ammonia, among others) which escape the system's boundary.

In the study of the energy involved in this production system (Table 5), 7,420,351.91 MJ of energy (energy consumed) were necessary to produce $3,411,461.00 \mathrm{MJ}$ of energy in products (energy converted), whereas the energetic efficiency or energy conversion efficiency of the system was 0.46 or $46 \%$. The results are close to those found by several authors, with conversion values varying from 25.29 to $41.73 \%$ (Santos \& Lucas Júnior, 2004; Souza et al., 2009; Veloso et al., 2012, 2014).

The amount of energy needed to produce $1 \mathrm{~kg}$ of live chicken for slaughter (Table 5) was $37.55 \mathrm{MJ}$, which is lower than that found by Santos \& Lucas Júnior (2004), working with broilers raised in conventional system with wooden facilities, $69.04 \mathrm{MJ} \mathrm{kg}^{-1}$ of live chicken. Values closer to the one found in this study were observed by Souza et al. (2009) and Veloso et al. (2012), who studied energy analysis in swine production and found values of 41.73 and $53.35 \mathrm{MJ} \mathrm{kg}^{-1}$ live pig for slaughter.
Table 5. Balance of total energy inputs and outputs (MJ) involved in the Darkhouse-type broiler chicken production system, during one production cycle (56 days), energetic efficiency and energy necessary to produce $1 \mathrm{~kg}$ of live chicken for slaughter

\begin{tabular}{lrr}
\hline \multicolumn{1}{c}{ Indicators } & Energy (MJ) \\
Inputs & & \\
Direct Energy & & $7,395,502.95$ \\
Indirect Energy & & $24,848.96$ \\
& & $7,420,351.91$ \\
\hline Outputs & & \\
Organic Compost & & $1,507,099.88$ \\
Chickens & & $1,904,365.04$ \\
& & $3,411,464.92$ \\
\hline Output-Input Balance & Total outputs: & $-4,008,889.99$ \\
Energetic efficiency & 0.46 \\
Energy invested in 1 kg of live chicken & 37.55 \\
\hline
\end{tabular}

According to Heidari et al. (2011), the use of energy in the production of broiler chickens is not efficient and ends up being detrimental to the environment due to the excessive use of natural resources. These authors also point out that the reduction in the use of fossil fuels and feeds would be useful not only to reduce the negative effects on the environment and human health, but also to maintain sustainability and decrease production costs.

There are few studies involving energetic analysis of biosystems, represented by the lack of data in the literature, which demonstrates the need for more studies and coefficients specific to the Brazilian conditions.

\section{Conclusions}

1. The studied system had energetic coefficient of 0.95 .

2. Feed consumption was considered as the main choke point of energy in the system.

3. The obtained conversion coefficient was equal to 37.55 MJ kg ${ }^{-1}$ of live chicken.

\section{Literature Cited}

Angonese, A. R.; Campos, A. T.; Zacarkim, C. E.; Matsuo, M. S.; Cunha, F. Eficiência energética de sistema de produção de suínos com tratamento dos resíduos em biodigestor. Revista Brasileira de Engenharia Agrícola e Ambiental, v.10, p.745-750, 2006. https:// doi.org/10.1590/S1415-43662006000300030

Campos, A. T.; Saglietti, J. R. C.; Campos, A. T. de; Bueno, O. de C.; Resende, H.; Gasparino, E.; Klosowski, E. S. Custo energético de construção de uma instalação para armazenagem de feno. Ciência Rural, v.33, p.667-672, 2003. https://doi.org/10.1590/ S0103-84782003000400013

Carvalho, R. H.; Soares, A. L.; Grespan, M.; Spurio, R. S.; Coró, F. A.; Oba, A.; Shimokomaki, M. The effects of the dark house system on growth, performance and meat quality of broiler chicken. Animal Science Journal, v.86, p.189-193, 2015. https://doi.org/10.1111/ asj. 12262 
Ebrahimi, S.; Gundoshmian, T. M.; Abdi, R.; Jadidi, M. R. Energy efficiency improvement for broiler production using nonparametric techniques. Agricultural Engineering International: CIGR Journal, v.18, p.121-132, 2016.

Fernandes, M. P.; Souza, A. M. T. Balanço energético: O consumo de energia na construção civil. Revista Brasileira de Tecnologia, v.13, p.22-36, 1982.

Funck, S. R.; Fonseca, R. A. Avaliação energética e de desempenho de frangos com aquecimento automático a gás e a lenha. Revista Brasileira de Engenharia Agrícola e Ambiental, v.12, p.91-97, 2008. https://doi.org/10.1590/S1415-43662008000100014

Heidari, M. D.; Omid, M.; Akram, A. Energy efficiency and econometric analysis of broiler production farms. Energy, v.36, p.6536-6541, 2011. https://doi.org/10.1016/j.energy.2011.09.011

Jasper, S. P.; Biaggioni, M. A. M.; Silva, P. R. A.; Seki, A. S.; Bueno, O. C. Análise energética da cultura do crambe (Crambe abyssinica Hochst) produzida em plantio direto. Engenharia Agrícola, v.30, p.395-403, 2010. https://doi.org/10.1590/S010069162010000300004

Lammers, P. J.; Kenealy, M. D.; Kliebenstein, J. B.; Harmon, J. D.; Helmers, M. J.; Honeyman, M. S. Energy use in pig production: An examination of current Iowa systems. Journal of Animal Science, v.90, p.1056-1068, 2012. https://doi.org/10.2527/jas.2010-3782

Meul, M.; Nevens, F.; Reheul, D.; Hofman, G. Energy use efficiency of specialized dairy, arable and pigfarms in Flanders. Agriculture, Ecosystems \& Environment, v.119, p.135-144, 2007. https://doi. org/10.1016/j.agee.2006.07.002
Mudahar, M. S.; Hignett, T. P. Energy requirements, technology, and resources in the fertilizer sector. In: Helsel, Z. R. (ed.). Energy in plant nutrition and pest control. Oxford: Elsevier, 1987. p.25-62.

Pimentel, D. Handbook of energy utilization in agriculture. Boca Raton: CRC, 1980. 475p.

Santos, T. M. B.; Lucas Júnior, J. de. Balanço energético em galpão de frangos de corte. Engenharia Agrícola, v.24, p.25-36, 2004. https:// doi.org/10.1590/S0100-69162004000100004

Souza, C. de V.; Campos, A. T.; Bueno, O. de C.; Silva, E. Análise energética em sistema de produção de suínos com aproveitamento dos dejetos como biofertilizante em pastagem. Engenharia Agrícola, v.29, p.547557, 2009. https://doi.org/10.1590/S0100-69162009000400005

Veloso, A. V. Análise ambiental e energética de sistema de produção de suínos com tratamento de dejetos em biodigestor. Lavras: UFLA, 2014. 192p. Tese Doutorado

Veloso, A. V.; Campos, A. T.; Paula, V. R. de; Dourado, D. C.; Yanagi Júnior, T.; Silva, E. B. Energetic efficiency of a deep bed swine production system. Engenharia Agrícola, v.32, p.1068-1079, 2012. https://doi.org/10.1590/S0100-69162012000600008

Vigne, M.; Martin, O.; Faverdin, A. P.; Peyraud, J. L. Comparative uncertainty analysis of energy coefficients in energy analysis of dairy farms from two French territories. Journal of Cleaner Production, v.37, p.185-191, 2012. https://doi.org/10.1016/j. jclepro.2012.07.005

Yilmaz, I.; Akcaoz, H.; Ozkan, B. An analysis of energy use and input costs for cotton production in Turkey. Renewable and Sustainable Energy Reviews, v.30, p.145-155, 2005. https://doi.org/10.1016/j. renene.2004.06.001 